\title{
VEIDO MANKŠTOS POVEIKIS BRANDAUS AMŽIAUS MOTERŲ VEIDO ODOS PARAMETRAMS
}

\author{
Raimonda Rauluševičienė, Margarita Drozdova-Statkevičienė, \\ Kristina Ramanauskienė, Ieva Račaitė \\ Šv. Ignaco Lojolos kolegija, Sveikatos mokslu ir technologiju katedra
}

Raktažodžiai: veido mankšta, veido raumenys, brandi veido oda, raukšlès, veido senèjimas.

\section{Santrauka}

Senatviniai pokyčiai labiausiai pastebimi veide, apima minkštuosius audinius ir juos palaikančias kaulines struktūras. Pagrindiniai sukeliantys veiksniai yra gravitacijos jèga, minkštujų veido audinių senejjimo procesai, kaulinio audinio remodeliacija, veido raumenų aktyvumas, stomatognatinès sistemos pokyčiai ir ultravioletinių spindulių poveikis. Senėjimo požymiai pirmiausiai pasireiškia nasolabialinèje srityje, trumpejja viršutinès lūpos keliamieji ir viršutinès lūpos kampo keliamieji raumenys, skruostų raumenys, mažèja skruostų zonos riebalinis audinys. Teigiama, kad atliekant veido mankštą, galima koreguoti vertikalias raukšles virš viršutinès lūpos, stiprinant lūpos žiedinio raumens vidurinę dalị, treniruojant didijji skruostų raumenị galima sumažinti nosies-lūpų raukšlès gylị, pagerinti medžiagų apykaitą, audinių regeneraciją bei kraujotakos ir limfotakos cirkuliaciją. Šio tyrimo tikslas - ịvertinti veido mankštos poveikị brandaus amžiaus moterų veido odos parametrams. Metodai. Tyrimui buvo atrinktos trys 45-60 metų moterys. Veido odos būklè buvo vertinama prieš mankštos kursą ir po jo, naudojant diagnostinį aparatą A-ONE Smart. Vertinimo ataskaitoje pateikiami rezultatai apie raukšles, drègmę, poras, pigmentaciją, sebumą, elastingumą, odos spalvą, odos temperatūrą. Veido mankštos programa susidejjo iš aštuonių savaičių kurso, kurị sudare du etapai: 1) paruošiamieji pratimai veido ir kaklo raumenu apšilimui ir atpalaidavimui; 2) pratimų programa veido ovalo raumenu stiprinimui ir atpalaidavimui. Rezultatai. Bendrasis veido raukšlès gylio parametras keitèsi visu trijų tyrimo dalyvių, tačiau didžiausi pokyčiai $(55,07$ proc.) pastebèti antrosios tyrimo dalyvès. Nagrinejjant atskirų veido zonų raukšlių gylio parametrus nustatyta, kad visoms tiriamosioms labiausiai mažėjo kaktos srities raukšlių gylis, buvo stebima ir kitų raukšlių mažèjimo tendencija. Išvados. Aštuonių savaičių veido mankštos programa padeda sumažinti veido odos raukšliu gylị ir pagerinti brandaus amžiaus moterų odos būklę. Aštuonių savaičių veido mankštos programa efektyviausia mažinti kaktos srities raukšles.

\section{Ivadas}

Senatviniai pokyčiai labiausiai pastebimi veide, o senèjimas yra neišvengiamas ir natūralus procesas. Veido senejjimas yra dinaminis procesas, apimantis minkštuosius audinius ir juos palaikančias kaulines struktūras [13]. Senejjimas yra neišvengiama žmogaus gyvenimo dalis, kuri palieka pedsakus veide. Tai raukšlès, odos suglebimas, pigmentacija, keratozinès papulès, telangiektazès ir komedonai [3].

Tiriant morfologinius pokyčius, veidą ịprasta skirstyti i trečdalius: viršutinis (kakta ir antakiai), vidurinis (akys, nosis ir skruostai) ir apatinis (lūpos, apatinis žandikaulis ir smakras) [2]. Pagrindiniai senatvinius pokyčius sukeliantys veiksniai yra gravitacijos jèga, minkštujų veido audinių senejjimo procesai, kaulinio audinio remodeliacija, veido raumenų aktyvumas, stomatognatinès sistemos kitimas ir ultravioletinių spindulių poveikis [11].

Senėjimo požymiai pirmiausiai pasireiškia nosies-lūpų, dar kitaip vadinamoje nasolabialinèje srityje, trumpejja viršutinès lūpos ir jos kampo keliamieji raumenys, skruostų raumenys, mažejja skruostų zonos riebalinis audinys [4]. Senstančio žmogaus oda plonèja, darosi sausesnè ir ne tokia elastinga, mažiau geba apsisaugoti nuo žalingo aplinkos poveikio, sukeliančio raukšlių atsiradimą [5]. Raukšlès yra natūrali senèjimo proceso dalis, todèl didèja brandaus amžiaus moterų susidomejjimas estetinèmis veido senejjimo problemų korekcijomis. Senèjimo problemos daugelį metų buvo sprendžiamos plastinès chirurgijos pagalba [9], tačiau šiuo metu populiarejja alternatyvūs jų sprendimo būdai, tokie kaip akupunktūra, akupresūra, veido raumenų masažai ir mankšta $[4,9]$. 
Literatūros duomenimis, veido raumenų mankštos efektyvumas veido atjauninimui vertinamas prieštaringai. Vieni mokslininkai negauna reikšmingų pokyčių, o kiti teigia, kad šie pratimai yra veiksmingas būdas mažinti smulkias raukšles ir suteikti veido odai elastingumo $[8,10]$. Tyrimų rezultatai parodè, kad veido mankšta galima koreguoti vertikalias raukšles virš viršutinès lūpos, stiprinant lūpos žiedinio raumens vidurinę dalį, o treniruojant didijj skruostų raumenį, galima sumažinti nosies-lūpų raukšlès gylị [10]. Manoma, kad veido mankšta pagerina medžiagų apykaitą, audinių regeneraciją, kraujotakos ir limfotakos cirkuliaciją [3]. Kitų autorių teigimu, veido pratimai turi neigiamą poveikį, kadangi raukšlių atsiradimas yra pasikartojančio odos judejjimo, kurị sukelia kartotiniai veido raumenų susitraukimai, rezultatas, kartu su kolageno ir elastino praradimu [3,8]. Mimikos raumenų spazmai formuoja raukšles ịvairiose veido zonose, o kramtomujų raumenų hipertonusas sukelia veido ovalo pakitimus, senstant išnyksta taisyklingas apatinio žandikaulio kampas [6]. Aktualu ịvertinti veido mankštos pratimų poveikị brandaus amžiaus moterų veido odos parametrams. Reikia pastebèti, kad pagrindinis mankštos uždavinys išlieka nepakitęs - visų veido raumenų treniravimu ir tonizavimu dažniausiai siekiama atjauninamojo efekto [7]. Tai labai aktualu, nes mimikos raumenys nejudina sąnarių ar kaulų, skirtingai nei kūno raumenys. Mimikos raumenys vienu galu tvirtai jungiasi prie kaulų, kitu - prie odos arba audinio gleivinès. Netreniruojami veido raumenys praranda tvirtumą, sutrumpèja ir traukia paskui save odą, kuri ilgainiui praranda elastingumą. Veido mankštos pratimai orientuoti ị raumenų tonuso didinimą, jų elastingumo koregavimą ir $\mathfrak{i}$ raumenų atpalaidavimo techniką. Dažnai vienos rūšies technikos taikymas nesuteikia teigiamo efekto, todèl aktualu parinkti ir taikyti tinkamus veido mankštos pratimus tinkamai veido daliai, atsižvelgiant ị veido raukšlių priežastis, kad būtu galima pasiekti teigiamą mankštos rezultatą veido odos parametrams.

Iki šiol nèra vieningos mokslininkų nuomonès apie veido mankštos poveikị veido raukšlių korekcijai, kadangi raukšlių ar veido ovalo pakitimai gali atsirasti ne tik dèl amžiaus, bet ir dèl gravitacijos ar netaisyklingos laikysenos.

Tyrimo tikslas - įvertinti veido mankštos poveikị brandaus amžiaus moterų veido odos parametrams.

\section{Tyrimo medžiaga ir metodai}

Tyrimas buvo atliktas Kauno Šv. Ignaco Lojolos kolegijoje, Sveikatos mokslų ir technologijų katedroje 2019 m. vasario-balandžio mènesiais. Tiriamieji pasirašè asmens informavimo ir sutikimo dalyvauti tyrime formą, prieš tai paaiškinus visus tyrimo ypatumus ir su tuo susijusius galimus nepatogumus. Tyrimo metu lai- kytasi Helsinkio deklaracijos ir tyrimų etikos principų.

Tiriamieji. Kriterinès atrankos būdu buvo atrinktos trys 45-60 metų moterys. Tyrimo dalyvès turejjo atitikti šiuos kriterinius reikalavimus: statinès ir dinaminès raukšlès veido srityje, veido oda praradusi elastingumą, sumažejęs odos tonusas, sumažèjęs drègmès lygis. Labai svarbus kriterijus buvo tiriamujų motyvacija ir suinteresuotumas sąžiningai atlikti joms skirtas užduotis.

Odos būklès vertinimas. Tiriamųjų veido odos būklè buvo vertinama veido diagnostiniu aparatu A-ONE Smart. Jame integruotas labai didelès raiškos fotoaparatas ir daugialypis jutiklis, kurie atlieka automatinę veido analizę, padarydami tris veido nuotraukas su normalia šviesa, su ultravioletine šviesa ir poliarizuota šviesa. Veido odos būklès ataskaitoje išskiriami šie pagrindiniai elementai: raukšlès, drègmè, poros, pigmentacija, sebumas, elastingumas, odos spalva, odos temperatūra. Aparatu atliekamas rezultatų palyginimas ir analizè. Palyginimas atliekamas su kliento amžiaus grupés parametrais ir idealios odos būklès parametrais. Aparatas taip pat nustato preliminarų biologinị amžių. Pirmasis veido odos vertinimas diagnostiniu aparatu buvo atliktas prieš pradedant veido mankštos pratimus. Antrasis vertinimas atliktas tyrimo pabaigoje, praejjus 8 savaitėms.

Veido mankštos programa. Aštuonių savaičių veido mankštos programa buvo dviejų etapų, sudaryta kosmetologo-kineziologo.

Pirmas etapas. Paruošiamieji pratimai veido ir kaklo raumenų apšilimui ir atpalaidavimui. Šis etapas truko dvi savaites. Tiriamosios buvo supažindintos su dviejų savaičių veido mankštos programomis, pagrindiniais veido raumenų ypatumais, apmokytos teisingai pasiruošti pratimams ir teisingai juos atlikti. Kiekviena tiriamoji gavo dviejų pirmujjų savaičiu veido mankštos programą, dienoraščius, kuriuos turejjo pildyti kiekvieną mankštos atlikimo dieną. Dienoraščio rašymu buvo siekiama užtikrinti veido mankštos pratimų atlikimą, todèl kiekviena tiriamoji turejjo pažymèti, ar paskirtają dieną atliko pratimus, ar ne. Dienoraštyje buvo pateikti laisvos formos klausimai, siekiant išsiaiškinti tiriamuju ịpročius ir patogiausią veido mankštos pratimų laiką.

Antras etapas. Pratimų programa veido ovalo raumenų stiprinimui ir atpalaidavimui. Šis etapas truko likusias šešias tyrimo savaites. Tiriamosios buvo supažindintos su naujomis veido mankštos programomis ir apmokytos teisingai atlikti naujus veido mankštos pratimus. Antrojo etapo metu tiriamosioms taip pat buvo išdalinti dienoraščiai, kuriuos turejjo pildyti viso tyrimo metu.

Tyrimo metu buvo atliekama ši sudetiné veido mankštos pratimų programa:

1) atlikus apžiūrą ir išanalizavus tiriamujų veido raumenų būklę, tyrimo dalyvèms buvo parengta individuali 
veido mankštos pratimų programa, sudaryta iš įvairių veido mankštos pratimų skirtingoms veido raumenų zonoms (kaklo, smakro, skruosto, lūpų, akių ir kaktos);

2) kiekviena tiriamoji buvo apmokyta teisingai atlikti veido raumenų apšilimo pratimus, kurie turèjo būti atliekami prieš pradedant veido mankštą;

3) mokymo metu dalyvavo kosmetologas-kineziologas, kuris stebejo ir koregavo pratimų atlikimo techniką.

Tiriamosios sutiko pratimus daryti namuose prieš veidrodị, juos atlikti sąžiningai ir daryti įrašus dienoraštyje.

Vykdydamos individualią veido mankštos pratimų programą, tiriamosios turejo atlikti:

- 2 savaites (kiekvieną dieną, be poilsio dienų) veido ir kaklo raumenų apšilimo pratimus. Pratimų trukmè 15 minučių;

- 6 savaites (6 dienas per savaitę, 1 diena poilsiui) veido ovalo raumenų stiprinimo ir atpalaidavimo pratimus. Trukmé 20-30 minučių.

Tyrimo metu buvo vykdomi kontroliniai susitikimai. Siekta užtikrinti, kad tyrimo dalyvès teisingai atliktų joms skirtus veido mankštos pratimus.

Statistinė duomenų analizė. Tyrimo duomenys buvo analizuojami naudojant Microsoft Excel kompiuterinę pro-

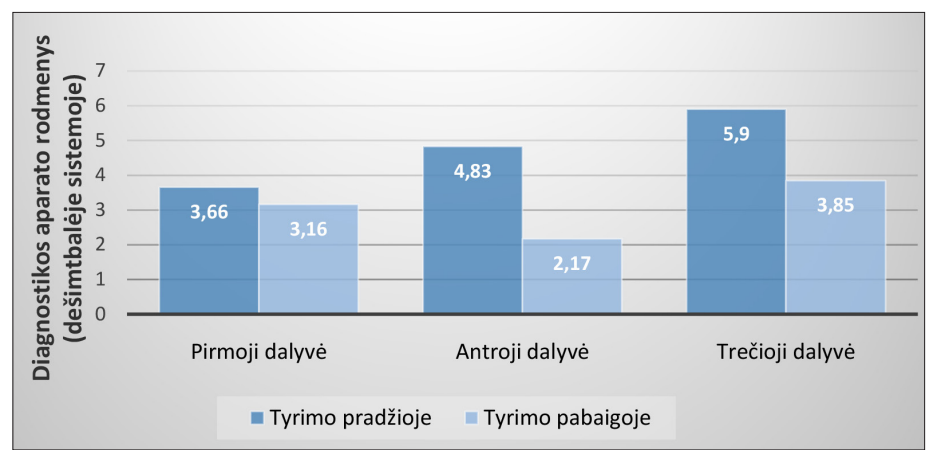

1 pav. Bendras veido raukšlių gylio parametras

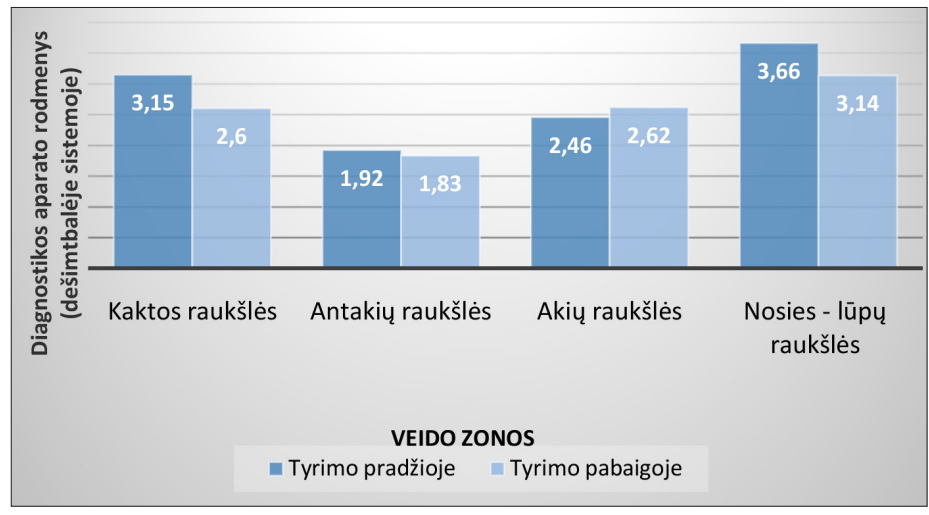

2 pav. Pirmosios tyrimo dalyvės veido zonų raukšlių parametrų kaita gramą. Buvo skaičiuoti aritmetiniai vidurkiai. Duomenys grafikuose pateikti kaip aritmetinis matavimų vidurkis.

\section{Tyrimo rezultatai}

Vienas iš svarbiausių veido odos parametrų rodiklių buvo pasirinktas raukšlès gylis. Raukšlès gylio parametras buvo vertinamas kaip bendras, apimantis visą veido raukšlių zoną, ir atskiras veido zonas. Bendras viso veido raukšlès gylio parametras keitèsi visų trijų tyrimo dalyvių. Šis rodmuo mažèjo gan ženkliai (1 pav.) visoms tiriamosioms, vertinant vizualiai ir diagnostiniu aparatu A-ONE Smart. Pirmosios tyrimo dalyvès raukšlių gylis sumažèjo 13,66 proc., antrosios - 55,07 proc., o trečiosios $-34,74$ procento (1 pav.).

Nagrinėjant veido zonų raukšlių gylio parametrus, stebima raukšlių mažejjimo tendencija. Pirmajai tyrimo dalyvei mažejo kaktos, antakių srities ir nosies-lūpų srities raukšlių gylis, tačiau išorinio akių krašto raukšlių gylis šiek tiek padidejo (2 pav.). Gauti rezultatai rodo, kad kaktos srityje raukšlių gylis sumažèjo 17,46 proc., antakių srityje sumažèjo 4,68 proc., akių srityje padidejo 6,50 proc., nosies-lūpu srityje sumažèjo 14,20 procento. Akių žiedinis raumuo yra aktyviausias veido srities raumuo, todèl šios zonos nežymus raukšlès gylio padidejimas gali būti siejamas su aktyvia mimika prasidejjus šiltajam sezonui, kai nebuvo naudojamos akių zoną apsaugančios priemonès (pvz., akiniai) ir tiriamoji nuolat buvo prisimerkusi.

Antrajai tyrimo dalyvei, nors ir neženkliai, raukšlès mažejo kaktos $(9,95$ proc.) ir akių zonoje $(31,35$ proc.), ypač sumažèjo antakių raukšlès gylis $(55,07$ proc.), šiek tiek padidèjo nosies-lūpų raukšlès rodmuo (6,73 proc.) (3 pav.).

Trečiajai tyrimo dalyvei labai ženkliai mažèjo kaktos (42,37 proc.) ir akių zonos raukšlès (48,96 proc.). Antakių raukšlių gylis ir ilgis mažèjo neženkliai (15,01 proc.). Nosies-lūpų raukšlių gylis nežymiai padidejo (6,31 proc.) (4 pav.).

\section{Diskusija}

Analizuojant moterų veido parametrus prieš ir po veido mankštos pratimu kurso, nustatyta veido raukšlių pokyčių dinamika. Gauti rezultatai leidžia matyti, jog visoms tiriamosioms mažèjo tiek bendras raukšlių gylio parametras, tiek atskirų veido zonų raukšlių parametrai. Rezultatai taip pat leidžia teigti, jog labiausiai raukšlès gylis mažèjo kaktos ir antakių srityje. Šioje veido zonoje raumenys dažniausiai įtempti, padidèjęs jų tonusas, nes tai yra aktyviausios veido zonos, padedančios išreikšti ịvairias mimikas, pvz., kai intensyviai šviečia saulè stengiamès prisimerkti, o kalbedami dažnai judiname kaktos zoną, to- 
dèl mankštos pratimai padeda raumenis atpalaiduoti.

Galime stebèti, jog po veido mankštos pratimų sumažèjo veido srities raukšlès, oda tapo skaistesnè, gražesnè. Tyrimo dalyvès tyrimo metu nenaudojo jokių papildomų veido priemonių ir nedare invazinių ar neinvazinių procedūrų, kurios galètų pagerinti veido odos parametrų rezultatus. Veido mankštos gali suteikti gerą efektą ir nieko nekainuoja, tačiau norint gauti gerus rezultatus, reikia įdèti daug darbo ir rasti laiko sau. Tyrimo dalyvès ir po tyrimo planavo tęsti veido mankštos užsièmimus.

Keitėsi ir atskirų veido zonų raukšlių rodikliai: tam tikrose zonose ženkliai mažèjo, o kai kuriose neženkliai didejjo. Dviejų tyrimo dalyvių neženkliai padidejo ar didèjo nosies-lūpų raukšlè, nors jos būtent čia mate geriausią pokyti, kuris ir nuotraukose buvo labai gerai matomas. Žinodami, kad nosieslūpų (nasoliabialinèje) zonoje susijungia daug veido raumenų (didysis skruosto raumuo, mažasis skruosto raumuo, lūpos keliamasis, lūpos kampo keliamasis, lūpos ir nosies sparnelio keliamasis), galime manyti, kad šios veido zonos raukšle dažniausiai pastebima, nes ji būna gili dèl spazmuotų raumenų. Šios zonos raukšlès gyliui svarbus ir limfos nutekejimas, kuris šioje zonoje dažniausiai būna sutrikęs. Galime daryti prielaidą, kad pagerèjus limfos nutekèjimui ir atpalaidavus raumenis šioje vietoje, raukšlès gylis, kartu su odos elastingumu, tiesiog nespejo pakisti.

Didžiausią perversmą veido mankštos istorijoje padaré 2018 m. JAMA Dermatology paskelbtas dermatologijos profesoriaus M. Alam ir bendraautorių mokslinis straipsnis [1], kuriame aprašomas tyrimas atliktas Šiaurės Vakarų Ilinojaus (JAV) universitete. Mokslininkai, nustatę kad 20 savaičių daryti veido pratimai davé teigiamų rezultatų, įrodè, jog 30 minučių per dieną atliekant veido pratimus, galima atrodyti jauniau. Atlikti tyrimai ịrodo, kad veido pratimai gali pagerinti veido išvaizdą ir sumažinti tam tikrus pastebimus senèjimo požymius.

M. Alam ir bendraautorių teigimu, pratimai didina ir stiprina veido raumenis, todèl veidas tampa tvirtesnis, labiau tonizuojamas ir formuojamas kaip jaunesnis veidas. Veido pratimai gali tapti pigia ir netoksiška minimalios invazinès kosmetinès chirurgijos alternatyva (ar papildomu gydymu) [1]. Mūsų tyrimo duomenys taip pat patvirtina, jog po 8 savaičių veido raumenų pratimų galima pastebèti matomus rezultatus. Mūsų tyrimo metu veido mankštos užsièmimai truko 20-30 minučių. Ilinojaus Valstijoje atliktame tyrime kiekvienos mankštos laikas buvo kontroliuojamas [1], tačiau mes šio tyrimo metu nefiksavome konkretaus laiko, nors programos trukmė buvo 20-30 minučių.

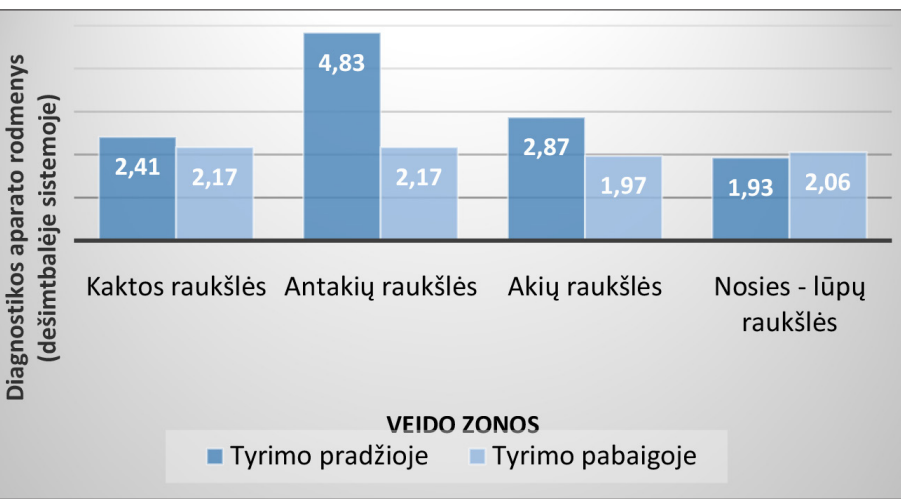

3 pav. Antrosios tyrimo dalyvès veido zonų raukšlių parametrų kaita

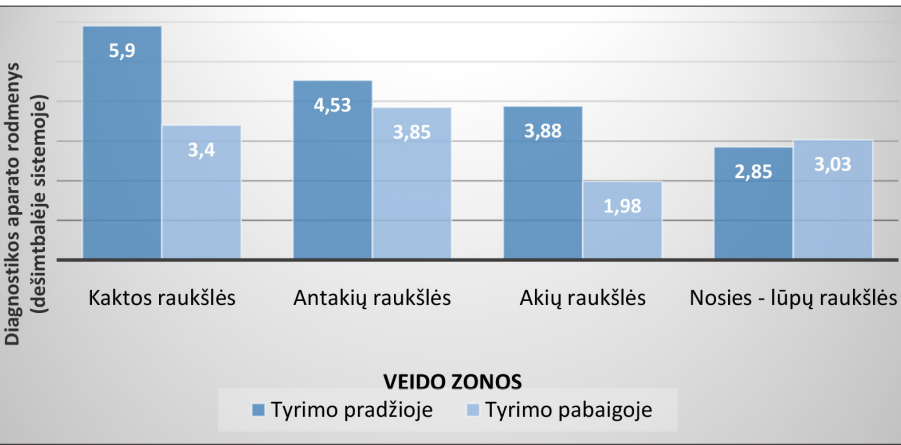

pav. Trečiosios tyrimo dalyvès veido zonų raukšlių parametrų kaita

Minètame tyrime [1] dalyvavo 27 moterys nuo 40 iki 65 metu, kurios darydavo veido mankštos pratimus. Tyrimas truko 20 savaičių, moterys turèjo atlikti 32 veido pratimus. Tyrimo dalyvès 8 savaites po 30 minučių darè apšilimo pratimus namuose, vèliau pratimus darydavo kas antrą dieną. Tyrimo metu 11 moteru atsisakè toliau dalyvauti tyrime. Liko 16 tiriamujųu, kurios baigè visą programą. Mūsų atveju, tiriamųjų amžius buvo panašus, todèl galime lyginti savo gautus rezultatus. Tiriamujų buvo 3, kadangi orientuotasi i kokybinį tyrimą.

Pokytis buvo vertinamas atliekant fotografijas. Tai buvo aklas tyrimas. Dermatologai nuotraukas ịvertino taikydami standartizuotą veido senèjimo skalę ir vertino kiekvienos tyrime dalyvavusios moters veidą. Buvo tiriama, kaip keičiasi veido išvaizda tyrimo pradžioje, tyrimui ịpusejus ir tyrimo pabaigoje. Tyrimo pradžioje dermatologai ịvertino tiriamąsias ir nustatė jų amžių - vidutiniškai 50,8 metų, o tyrimo pabaigoje tiriamosioms buvo nustatytas 48,1 metų amžiaus vidurkis. Tai ịrodo, kad moterų išvaizda per 20 savaičių laikotarpi pasikeite taip, kad jos atrode jaunesnès beveik trejais metais. Pratimai sustiprino veido raumenis, todèl veidas tapo tvirtesnis. Baigusios tyrimą moterys teigè, kad veido pratimų programa gana sunki, tačiau tyrimas vis dèlto buvo 
pagrịstas. Jei kas nors yra motyvuotas ir pasirengęs daryti treniruočių programą, tai jiems nesukels jokios žalos. Tai tikrai verta pabandyti žmonėms, kurie nèra patenkinti savo veido oda, jos raukšlejjimusi ir kitais defektais $[1,12]$. Mes savo tyrime taip pat atlikome veido fotografijų vertinimą, o aparatu A-ONE Smart buvo nustatomas tiriamujų veido odos amžius. Tai leido daryti analogiškas išvadas, nes po atliktu procedūrų kurso mūsų tiriamųjų nustatytas amžius taip pat sumažèjo 1 metais. Galima manyti, kad mūsų pratimų programą taikant ilgesnị laiką, galimi panašūs rezultatai, kaip ir minèto [1] tyrimo.

\section{Išvados}

1. Atlikus tyrimą nustatyta, kad aštuonių savaičiu veido mankštos programa padeda sumažinti brandaus amžiaus moterų veido odos raukšlių gylị ir pagerinti odos būklę.

2. Aštuonių savaičių veido mankštos programa efektyviausia kaktos srities raukšlių mažinimui.

\section{Literatūra}

1. Alam M, Walter AJ, Geisler A, Roongpisuthipong W, Gary Sikorski G, Tung R, Poon E. Association of facial exercise with the appearance of aging. JAMA Dermatology 2018; 154(3):365-367

https://doi.org/10.1001/jamadermatol.2017.5142

2. Coleman SR, Grover R. The anatomy of the aging face: volume loss and changes in 3-dimensional topography. Aesthetic Surgery Journal 2006;26(1):4-9.

https://doi.org/10.1016/j.asj.2005.09.012

3. De Vos MC, Van den Brande H, Boone B, Van Borsel J. Facial exercises for facial rejuvenation: a control group study. Folia Phoniatr Logopaedica. 2013;65(3):117-122.

https://doi.org/10.1159/000354083

4. Hwang UJ, Kwon OY, Jung SH, Ahn SH, Gwak, GT. Effect of a facial muscle exercise device on facial rejuvenation. Aesthetic Surgery Journal 2018;38(5):463-476. https://doi.org/10.1093/asj/sjx238

5. Nordqvist C. Rosacea: causes, symptoms and treatments. http://www.medicalnewstoday.com/articles/160281.php.

6. Osminina $\mathrm{N}$. Veido senejimo anatomija arba kosmetologijos mitai. Klaipeda: Baltic Printing House, 2012;11-14.

7. Dan O. Jauninantis veido ir kūno masažas. Leidykla: Obuolys. 2011:176.

8. Roizen M, Oz M. You: being beautiful. New York, Free Press 2008.

9. Van Borsel J, De Vos MC, Bastiaansen K, Welvaert J, Lambert J. The effectiveness of facial exercises for facial rejuvenation: a systematic review. Aesthetic Surgery Journal. 2014;34(1):22-27. https://doi.org/10.1177/1090820X13514583

10. Van Lieshout PH, Bose A, Namasivayam AK. Physiological effects of an 8-week mechanically aided resistance facial exercise program. Int J Orofacial Myology 2002;28:49-73.

11. Uiotto J. Understanding premature skin aging. New England Journal of Medicine 1997; 337:1463-1465. https://doi.org/10.1056/NEJM199711133372011

12. Willis $\mathrm{O}$. Face yoga just might reduce signs of aging. $\mathrm{ABC}$ Magazine 2018.

13. Zimbler MS, Kokoska MS, Thomas JR. Anatomy and pathophysiology of facial aging. Facial Plast Surg Clin North Am 2001; 9(2):179-187.

\section{EFFECTS OF FACIAL EXERCISE ON FACIAL SKIN PARAMETERS IN MATURE WOMEN R. Rauluševičienė, M. Drozdova-Statkevičienė, K.Ramanauskienė, I. Račaitė}

Keywords: facial exercise, facial muscles, mature facial skin, wrinkles, facial aging.

Summary

Changes in aging are most noticeable in the face, involving the soft tissues and the bone structures that support them. The main factors influencing aging changes are gravitational force, soft facial tissue aging processes, bone remodeling, facial muscle activity, changes in the stomatognathic system, and exposure to ultraviolet light. Signs of aging appear primarily in the nasolabial area, shortening of the upper lip lifting and upper lip corner lifting muscles, cheek muscles and shrinking adipose tissue in the cheek area. It is said that facial exercises can correct vertical wrinkles above the upper lip, strengthen the middle part of the orbicular muscle, train the large cheek muscle can reduce the depth of the nose-lip wrinkle, improve metabolism, tissue regeneration and circulatory and lymphatic circulation. The aim of this study was to evaluate the effect of facial exercise on facial skin parameters in mature women. Methods: Three women aged 45-60 years were selected for the study. Facial skin condition was assessed before and after the exercise course using the A-ONE Smart diagnostic device. The evaluation report includes results on wrinkles, moisture, pores, pigmentation, sebum, elasticity, skin color, skin temperature. The facial exercise program consisted of an eight-week course consisting of two stages: (1) Preparatory exercises are designed to warm up and relax the face and neck muscles; (2) The exercise program is designed to strengthen and relax the facial oval muscles. Results: The total facial wrinkle depth parameter changed for all three study participants, but the largest changes were observed for the second participant - 55.07 perc. Examining the parameters of the depth of wrinkles in individual facial areas, we found that the depth of wrinkles in the forehead area decreased the most for all subjects, and a decreasing trend of other wrinkles was also seen. Conclusions: (1) The study found that an eight-week facial exercise program helps reduce the depth of wrinkles in the facial skin and improve skin condition in mature women. (2) An eightweek facial exercise program is most effective for reducing wrinkles in the forehead area.

Correspondence to: r.raimonda@yahoo.com

Gauta 2020-12-21 